\title{
CRIMINAL PROCEDURE: GOVERNMENT HAS DUTY TO IMPLEMENT EFFECTIVE GUIDELINES TO PRESERVE DISCOVERABLE EVIDENCE
}

In United States $v$. Bryant, ${ }^{1}$ the Court of Appeals for the District of Columbia Circuit held that the duty to disclose evidence is operative as a duty of preservation upon the Government and that judicial sanctions will be imposed where disclosure is impossible due to loss of discoverable evidence, unless the Government attempted in good faith, through adherence to rigorous and systematic procedures, to preserve all discoverable evidence amassed during criminal investigations. Carlton Bryant and William Turner were convicted for aiding and abetting the sale of heroin to Pope, a government agent, whose testimony comprised the basis of the case against the defendants. According to Agent Pope, the sale was negotiated in his motel room on two separate occasions-once with Bryant and Johnson, a third accomplice, and on a subsequent occasion with Turner and Johnson. Other government agents were listening to and tape recording the conversations from an adjoining room. Defense counsel unsuccessfully attempted to obtain this tape during the pretrial proceedings. The Assistant United States Attorney informed defense counsel that a tape had been made but was never turned over to the prosecution and was apparently lost by the Bureau of Narcotics and Dangerous Drugs. At a hearing on a defense motion to discover the tape or, alternatively, to dismiss the indictment, the government agent responsible for the recording admitted that he had made no effort to preserve the tape. ${ }^{2}$ The trial judge denied discovery, and both defendants were convicted at trial. The court of appeals remanded the cases for further hearings, instructing the district court to consider the extent to which negligence or bad faith was involved in the agent's failure to preserve, the importance of the evidence lost, and the proper sanction to be imposed.

A defendant's right to discovery in criminal cases was non-existent

1. - F.2d _- (D.C. Cir. 1971), considered together with a companion case, United States $v$. Turner.

2. Apparently, according to agency procedure, Agent Warden would have considered this tape to be of evidentiary value only had the narcotics purchaser been an outside informant rather than a Bureau agent. Id. at 
at common law, ${ }^{3}$ and no such right was recognized by the federal courts ${ }^{4}$ until the addition of rule 16 to the Federal Rules of Criminal Procedure. ${ }^{5}$ The only exception to this non-access to material evidence was in circumstances where the prosecutor acted in such bad faith as to infringe upon the defendant's constitutional right to due process. Thus, in Mooney y. Holohan, ${ }^{6}$ the Supreme Court held that the defendant was denied due process when the prosecutor contrived a conviction by deliberately deceiving the court and the jury with testimony known to be perjured. The Court extended this holding in subsequent cases, finding a denial of due process where the prosecutor failed to correct unsolicited perjured testimony; ${ }^{7}$ where the prosecutor used perjured testimony relevant only to the defendant's sentence and not to his guilt; ${ }^{8}$ and where the prosecutor deliberately suppressed evidence favorable to the defendant. ${ }^{9}$ Ultimately, in Brady $v$. Maryland,$^{10}$ the Court held that due process was violated whenever the prosecution suppressed requested evidence which was favorable to the defendant's case, irrespective of whether the prosecutor was acting in good or bad faith. The intentions of the prosecution were immaterial because the holding was designed to guarantee the accused a fair trial, not to punish the prosecutor for his misdeeds. Although the Supreme Court has refused to formulate a precise definition of the extent to which the prosecution has a duty to disclose requested evidence, ${ }^{11}$ Brady at least imposed a general duty not to suppress evidence which would tend to exculpate the defendant or reduce the severity of the penalty imposed. ${ }^{12}$

Rule 16 of the Federal Rules of Criminal Procedure ${ }^{13}$ and the

3. See 2 F. Wharton, Criminal Evidence $\$ 671$ (12th ed. 1955); 6 J. Wigmore, Evidence $\S \S 1859 \mathrm{~g}, 1863$ (3d ed. 1940); Grady, Discovery in Criminal Cases, 1959 U. ILl. L.F. 827 (1959); Moore, Criminal Discovery. 19 Hastings L.J. 865 (1968); Comment, Pre-Trial Disclosure in Criminal Cases, 60 YaLE L.J. 626 (1951).

4. See, e.g., United States v. Rosenfeld, 57 F.2d 74, 76 (2d Cir.), cert. denied, 286 U.S. 556 (1932); United States v. Garsson, 291 F. 646 (S.D.N.Y. 1923); United States v. Violon, 173 F. 501 (S.D.N.Y. 1909). See also Fontana, Discovery in Criminal Cases-A Survey of the Proposed Rule Changes, 25 MD. L. Rev. 212, 214 (1965); Moore, supra note 3, at 869-70.

5. FED. R. CRIM. P. 16 (1946).

6. 294 U.S. 103 (1935).

7. Napue v. lllinois, 360 U.S. 264 (1959).

8. Alcorta v. Texas, 355 U.S. 28 (1957).

9. Pyle v. Kansas, 317 U.S. 213 (1942).

10. 373 U.S. 83 (1963).

11. Giles v. Maryland, 386 U.S. 66, $73-74$ (1967).

12. Brady v. Maryland, 373 U.S. 83, 87-88 (1963).

13. For the pertinent portions of the text of rule 16 see notes 16 and 24 infra. 
Jencks Act ${ }^{\text {t }}$ have largely precluded the defendant's need to rely upon constitutional grounds to obtain evidence. ${ }^{15}$ Rule $16(a){ }^{16}$ provides for a limited right to discovery of the defendant's written or recorded statements or confessions without any showing of materiality. Discovery is not mandatory under the rule but rather is within the discretion of the trial judge. Lower courts and commentators seem to agree, however, that under rule 16(a) the defendant should be accorded a presumptive right to discover his own statements or confessions. ${ }^{18}$ Even assuming a defendant's presumptive right to discover under rule 16(a) the question remains whether the word "statement" as used in 16(a) was intended to encompass a defendant's statements made during the course of a crime and contemporaneously recorded by the Government. The Rules Advisory Committee's Note, emphasizing the broad scope of discovery intended in the rule, suggests that it should not be restricted to formal statements of past occurrences but should apply to pre-arrest statements as well. ${ }^{19}$ The ABA Project on Minimum Standards for Criminal Justice ${ }^{20}$ clearly supports this broad approach to discovery

14. 18 U.S.C. $\$ 3500$ (1964). For a partial text of the Jencks Act, see note 30 infra.

15. Only if the defense fails to bring the item sought within the language of rule 16 or the Jencks Act is it necessary to rely upon the due process clause to obtain access to evidence. Such a situation would be relatively rare where these two statutes are broadly interpreted, as in the Bryant case. See also United States v. Crisona, 416 F.2d 107, 112-16 (2d Cir. 1969). Probably, the evidence that one is constitutionally entitled to discover is less than what he can diseover under rule 16 and the Jencks Act. See id.

16. Rule 16(a) provides:

Upon motion of a defendant the court may order the attorney for the government to permit the defendant to inspect any copy or photograph any relevant (1) written or recorded statements or confessions made by the defendant, or copies thereof, within the possession, custody or control of the government, the existence of which if known, or by the exercise of due diligence may become known, to the attorney for the government. ...

The fact that the showing of materiality, required in rule 16 before the 1966 amendment, was deleted in the amended rule 16(a), but retained in the amended rule 16(b), supports an inference that the draftsmen did not intend 16(a) to require a showing of materiality. $4 \mathrm{~W}$. BARRON \& $\mathrm{A}$. Holtzoff, Federal Practice and Procedure § 2033, al 61 (Supp. 1967). See note 34 infra.

17. See notes 16 supra and 24 infra. Both rule 16(a) and $16(\mathrm{~b})$ begin: "Upon motion of a defendant the court may order. . .."

18. See United States v. Crisona, 416 F.2d 107 (2d Cir. 1969); United States v. Isa, 413 F.2d 244, 248 (7th Cir. 1969); Uniled States v. Projansky, 44 F.R.D.550, 558 (S.D.N.Y. 1968); United States v. Federman, 41 F.R.D. 339, 341 (S.D.N.Y. 1967). See also 8 J. MoorE, Federal Practice if 16.05(1) (2d ed. 1965); 1 C. Wright, Federal Practice and Procedure § 253, at 500 (1969) [hereinafter cited as WrIGHT]; Moore, supra note 3, at 871.

19. See Advisory Committee's Note to FED. R. CRIM. P. 16(a)(1).

20. aba Standards Relating to Discovery and Procedure Before Trial (Tent. Draft 1969). 
and recommends that the word "statements" be interpreted to include any utterance of the defendant, whether recorded surreptitiously or with his knowledge and regardless of to whom the statement was directed. ${ }^{21}$ Recent federal decisions in accord with this interpretation have construed rule 16(a) to allow discovery of statements unwittingly furnished to the prosection through secret recording devices, ${ }^{22}$ noting that incriminating, secretly recorded remarks are potentially more damaging than formal confessions of guilt since the defendant would be unaware that his remarks were being taped. ${ }^{23}$ As a potential alternative to discovery under rule 16(a), rule $16(\mathrm{~b})$ provides for pre-trial discovery of "books, papers, documents, tangible objects . . . or copies or portions thereof."24 Arguably, if a surreptitious recording of a defendant's remarks is not encompassed by rule 16(a), it would constitute a "tangible object" within the scope of rule $16(\mathrm{~b}) .^{25}$ The fact that $16(\mathrm{~b})$ specifically exempts from discovery only "statements made by government witnesses . . . to agents of the government" indicates that the defendant's own statements are covered by the rule. In contrast to rule 16(a), however, discovery under 16(b) requires "a showing of materiality to preparation of [the defendant's] defense and that the request is reasonable." ${ }^{26}$ This requirement of materiality and reasonableness has been liberally construed; anything that the prosecution intends to use as evidence against the defendant is deemed material, and therefore a request for its discovery is reasonable. ${ }^{27}$ Even

21. Id. at 61-62.

22. United States v. Crisona, 416 F.2d 107, 114-15 (2d Cir. 1969); Davis v. United States, 413 F.2d 1226, 1231 (5th Cir. 1969); United States v. Lubomski, 277 F. Supp. 713, 721 (N.D. III. 1967); United States v. Iovinelli, 276 F. Supp. 629, 631 (N.D. IIl. 1967); United States v. Leighton, 265 F. Supp. 27, 34 (S.D.N.Y. 1967).

23. United States v. Lubomski, 277 F. Supp. 713, 721 (N.D. III. 1967).

24. Rule 16(b), in full, provides:

Upon motion of a defendant the court may order the attorney for the government to permit the defendant to inspect and copy or photograph books, papers, documents, tangible objects, buildings or places, or copies or portions thereof, which are within the possession, custody or control of the government, upon a showing of materiality to the preparation of his defense and that the request is reasonable. . . [ [ ] ]his rule does not authorize the discovery or inspection of . . . statements made by government witnesses

... to agents of the government ....

25. See United States v. Fassler, 46 F.R.D. 43 (S.D.N.Y. 1968); United States v. Iovinelli, 276 F. Supp. 629, 631-32 (N.D. 1II. 1967).

26. FED. R. CRIM. P. 16(b). See note 24 supra.

27. See, e.g., United States v. Hrubik, 280 F. Supp. 481 (D. Alaska 1968); United States v. Reid, 43 F.R.D. 520, 522 (N.D. III. 1967); cf. United States v. Pilnick, 267 F. Supp. 791, 801 (S.D.N.Y. 1967). See also WRIGHT § 254, at 513; Rezneck, The New Federal Rules of Criminal Procedure, 54 Geo. L.J. 1276, 1279 (1966). 
where the prosecution does not plan to use the sought item against the defendant, 16(b) may permit its discovery, so long as the defendant desires to introduce the evidence in his own behalf. ${ }^{28}$ Therefore, the request for discovery is reasonable, and the item sought is material, when the evidence tends to support the defendant's case or undermine that of the prosecution.

In Jencks $v$. United States, ${ }^{29}$ the Supreme Court held that the defendant must be allowed to inspect all prior statements by government witnesses touching upon the subject matter of their testimony. The Jencks Act, a codification of the Jencks holding, provides that after the government witness has testified, the defendant is entitled, upon request, to inspect all prior statements of that witness insofar as they are relevant to his direct testimony. ${ }^{30}$ If the Government elects not to produce discoverable Jencks statements, the statute provides that the court shall strike the testimony of the government's witness from the record. ${ }^{31}$ The statute specifically defines the word "statement" to include tape recordings of a witness' oral statement to a government agent, ${ }^{32}$ and the courts have further construed this language to require the production of statements made

28. See, e.g., United States y. Aadal, 280 F. Supp. 859 (S.D.N.Y. 1967). See also WRIGHT $\S 254$, at 513-14; Rezneck, supra note 27, at 1279.

29. 353 U.S. 657 (1957).

30. 18 U.S.C. $\$ 3500$ (1964):

(a) In any criminal prosecution brought by the United States, no statement or report in the possession of the United States which was made by a Government witness . . to an agent of the Government shall be the subject of subpena, discovery, or inspection until said witness has testified on direct examination in the trial of the case.

(b) After a witness called by the United States has testified on direct examination, the court shall, on motion of the defendant, order the United States to produce any statement ... of the witness in the possession of the United States which relates to the subject matter as to which the witness has testified.

....

(d) If the United States elects not to comply with an order of the court . . to deliver to the defendant any such statement . . . the court shall strike from the record the testimony of the witness....

(e) The term "statement". . . means-

....

(2) a stenographic, mechanical, electrical, or other recording . . . which is a substantially verbatim recital of an oral statement made by said witness to an agent of the Government and recorded contemporaneously with the making of such oral statement.

31. Id. § 3500(d) (1964).

32. Id. § $3500(\mathrm{e})(2)$. 
by one government agent to another. ${ }^{33}$ Unsettled, however, is the question of whether the Jencks Act extends to tape recordings of conversations which were recorded by a government agent during the course of a crime or whether the statute is strictly confined to statements of past occurrences. The Second Circuit has interpreted the statute broadly, requiring production of any recording of a government witness' statement so long as the taping was directed by government agents as part of their investigative duties. ${ }^{34}$

The court of appeals in Bryant concluded that the tape recording of the motel room conversations between the defendants and Agent Pope should have been preserved for discovery pursuant to both constitutional and statutory safeguards. Because the tape had been "lost" by the Government, its content was unknown and the court could not know what effect, if any, disclosure would have had upon the defendant's case. Nevertheless, since there was an "unavoidable possibility that the tape might have been significantly 'favorable' to the accused,"35 the court extended the due process requirement to the missing tape. The court reasoned that if the duty to disclose were invocable only when the contents of the undisclosed evidence was already known, the duty could be circumvented by destroying the evidence, rather than refusing to reveal it. Exclusive reliance upon the constitutional duty of disclosure was unnecessary, however, because the court held that the missing tape was explicitly included within those statements discoverable under rule 16 of the Federal Rules of Criminal Procedure. Rule 16(a), providing for discovery of "recorded statements or confessions made by the defendant," was broadly construed to encompass the defendant's pre-arrest remarks which were surreptitiously taped by government agents. Even conceding a narrow interpretation of 16 (a) to cover only formal statements of past occurrences, the court concluded that, in the alternative, defendants' statements would be discoverable as a "tangible object" under rule 16(b). Presumably, the court considered rule $16(\mathrm{~b})$ 's requirement of materiality and reasonableness to be satisfied by the "unavoidable possibility" that the tape might tend to exculpate the defendants.

33. Karp v. United States, 277 F.2d 843, 848 (8th Cir.), cert. denied, 364 U.S. 842 (1960); United States v. O'Conner, 273 F.2d 358, 360-61 (2d Cir. 1959); Holmes v. United States, 271 F.2d 635, 638-39 (4th Cir. 1959); United States v. Prince, 264 F.2d 850, 852 (3d Cir. 1959).

34. Compare United States v. Crisona, 416 F.2d 107, 113-14 (2d Cir. 1969) and United States v. Birnbaum, 337 F.2d 490, 498 (2d Cir. 1964), with United States v. Sopher, 362 F.2d 523, 525-26 (7th Cir. 1966).

35. -F.2d -(D.C. Cir. 1971). 
Finally, the court touched upon the possibility that the tape fell within the scope of the Jencks Act requirement that the defendant be allowed to inspect all recordings of oral statements made by government witnesses to government agents which are relevant to the witnesses' direct testimony. The court, though, refused to decide whether the statutory language reached Agent Pope's conversation with the defendants, since the Jencks Act would not have been applicable until the completion of Agent Pope's direct testimony and the tape already was held to be discoverable at the pre-trial stage under rule 16 .

Upon finding that the prosecution was both constitutionally and statutorily obligated to produce the tape for the defendant's inspection, the court still faced the problem of the extent to which the tape's disappearance mitigated this duty. The court rejected the prosecution's contention that loss per se would obviate the disclosure requirement, since disclosure could be avoided simply by destroying the evidence before prosecution was instigated or before the defense sought discovery. Rather, the court held that once the Government has possession of evidence, the duty of disclosure becomes an obligation to preserve the evidence. Where the evidence is not preserved, as in the present case, the court concluded that the imposition of judicial sanctions upon the prosecution should depend upon the circumstances surrounding the loss. ${ }^{36}$ Citing United States $v$. Augenblick ${ }^{37}$ where the Supreme Court refused to impose sanctions when the Government lost a tape subject to inspection under the Jencks Act, the court of appeals concluded that the prosecution must sustain a heavy burden of explaining any loss of evidence, but that no sanctions would be imposed if the Government makes a good faith effort "to follow rigorous and systematic procedures designed to preserve all discoverable evidence gathered in the course of a criminal investigation." 38 The court suggested that each investigative agency would be allowed to formulate its own procedural guidelines, according to what was best suited to its mode of operation; but such procedure would be subject to judicial scrutiny concerning the guidelines' effectiveness in preserving evidence. Since no such guidelines existed at the Bureau of Narcotics and Dangerous Drugs, the court was forced to reach a disposition of the Bryant case through a less refined approach. Although concluding that under the

36. Id. at $\overline{\text { 37. } 393 \text { U.S. } 348 \text { (1969). }}$
38. F. F. 
circumstances the government agent was negligent in failing to preserve the tape, the majority rejected the sanction of a new trial. Since the tape would still be unavailable at a new trial and if Agent Pope's testimony were stricken from the record for that reason, the prosecution's case would be destroyed, and a new trial would be pointless. Unwilling to make the choice between affirming or dismissing, the majority, indicating that the harsher sanctions would apply in the future, remanded the case to the district court for further testimony from the government agents in order to "clarify the degree of negligence, and the possibility of bad faith" in the handling of the tapes. ${ }^{39}$

The inability of the court to reach a final disposition given the facts in the record and the remand of the case in an effort to obtain further findings upon the circumstances of the tape's disappearance clearly indicate the court's hesitancy summarily to impose judicial sanctions upon the prosecution, where no bad faith is exhibited in failing to preserve the tapes. Yet, there is every reason to expect that these same difficulties involving the preservation of relevant evidence will be encountered in future cases. In anticipation of this continuing problem, the court of appeals placed the burden on the Government to make a good faith effort to preserve all evidence and ordered investigative agencies to adhere to self-developed guidelines designed to ensure preservation. Rather than attempting to force all agencies to abide by one rigid set of guidelines, the court chose the more realistic and probably more functional approach of allowing each agency to promulgate guidelines within its own framework of operations. This ruling placed the agencies on notice that in the future sanctions would be imposed for the negligent failure to preserve potentially material evidence; only good faith adherence to effective procedural guidelines would enable the Government to escape judicial sanctions. For the purpose of applying the decision in Bryant to future losses of evidence by government agencies, the cases which will arise conveniently divide into three basic situations. First, if the agency promulgates and consistently complies with effective guidelines, but nevertheless, loses evidence, no sanctions will be imposed, since the agency did all that Bryant requires. On the other hand, Bryant will just as obviously dictate the imposition of sanctions in the situation where the agency which loses evidence has implemented either insufficient guidelines or no guidelines at all. So long as the circumstances accompanying the

39. Id. at 
agency's loss of evidence approximate one of these two extremes, the judicial disposition of the cases should be simple. However, the courts will encounter difficulty in situations which fit neither of the two extremes provided for in Bryant. Suppose, for example, that while the agency adopts effective guidelines which it regularly follows, one of its agents fails to adhere strictly to the guidelines in a particular case and, either as a result of this laxity, or by coincidence, loses the evidence. Obviously, the agency's employee was negligent in performing his duties, and yet it appears that the agency took every foreseeable precaution to preserve evidence in its possession. Whether the loss of evidence under such circumstances should summon the imposition of sanctions is unclear from the Bryant case. Assuming, arguendo, that sanctions should be invoked against the agency, the court then must face the additional problem of determining the appropriate sanction. In a factual situation similar to Bryant, where the testimony of government agents comprises the basis of the prosecution's case, the striking of the agents' testimony would be comparable to dismissal of the charge against the defendant..$^{40}$ Furthermore, since this sanction is actually meted out to the prosecution rather than to the investigative agency which lost the evidence, its effectiveness in preventing further losses is questionable. To merely fine the negligent agent, however, would do nothing to alleviate the harm that the loss of evidence has caused to the defendant. In reality, there may be no effective solution to the problem of loss in the situations approximating neither of the extremes provided for in Bryant. Yet, while Bryant did not solve all the problems which will confront the courts in future cases involving loss of evidence, it did provide a procedure which may significantly reduce the likelihood that such losses will occur.

40. Id. at ___ See the pertinent text of 18 U.S.C. $\S 3500(\mathrm{~d})$, supra note 30 . 